\title{
PENGARUH KUALITAS LAYANAN DAN KEPERCAYAAN TERHADAP KEPUASAN PELANGGAN
}

\author{
Zefanya \\ Program Studi Magister Manajemen Universitas Tarumanagara \\ Zefanyamardianto@yahoo.com
}

\begin{abstract}
The aim of this study are: Frist, to explore the effect of service quality towards customer satisfaction. Second, to explore the effect of trust towards customer satisfaction. The method of data collection is convenience sampling. The sample of this research are collected from 186 respondent, who used one of these online shops in Jakarta. The technique of data analysis used in this study was regression analysis via the statistical package for social sciences computer programme version 18 . The result are: (1) service quality has a positive impact towards customer satisfaction; (2) trust has a positive impact towards customer satisfaction.
\end{abstract}

\begin{abstract}
Abstrak :Tujuan dari penelitian ini adalah: Frist, untuk mengeksplorasi pengaruh kualitas layanan terhadap kepuasan pelanggan. Kedua, untuk mengeksplorasi pengaruh kepercayaan terhadap kepuasan pelanggan. Metode pengumpulan data adalah convenience sampling. Sampel penelitian ini dikumpulkan dari 186 responden, yang menggunakan salah satu toko online di Jakarta. Teknik analisis data yang digunakan dalam penelitian ini adalah analisis regresi melalui paket statistik untuk program komputer ilmu sosial versi 18 . Hasilnya adalah: (1) kualitas layanan memiliki dampak positif terhadap kepuasan pelanggan; (2) kepercayaan memiliki dampak positif terhadap kepuasan pelanggan.
\end{abstract}

Keywords : service quality, trust, customer satisfaction

\section{PENDAHULUAN}

Dewasa ini, dengan meningkatnya pertumbuhan ekonomi disertai dengan perkembangan teknologi suatu negara menyebabkan tingkat kebutuhan konsumen terus meningkat. Dahulu yang dilakukan secara manual kini dilakukan dengan menggunakan teknologi, sehingga merubah gaya hidup konsumen yang berpengaruh terhadap perilaku pembelian konsumen yang menginginkan data yang akurat dan cepat, dimana dahulu konsumen membeli produk atau jasa harus bertatap muka antara pembeli dan penjual untuk mendapatkan kesepakatan. Akan tetapi dengan kemajuan teknologi sekarang ini khususnya internet membuat jarak, waktu, biaya menjadi lebih efisien dan menjadi solusi dalam melakukan transaksi. Saat ini dengan adanya internet mendorong perusahaan untuk membuat strategi pemasaran yang tepat dan membuat inovasi baik melalui produk ataupun jasa. Hal ini disebabkan karena adanya perubahan persaingan bisnis yang mengunakan internet sebagai media untuk melakukan transaksi dan memasarkan produk atau jasa yang disebut dengan sistem e-commerce. Persaingan didalam sebuah industri mengharuskan perusahaan untuk dapat membentuk tingkat kepuasan pelanggan yang tinggi. Pelanggan yang puas akan memberikan dampak positif bagi perusahaan. Disamping itu, dengan tingkat kepuasan pelanggan yang tinggi akan dapat mengukur sejauh mana perusahan dapat bersaing dalam pasar untuk mendapatkan keuntungan, maka perusahaan memiliki tujuan dasar yaitu mengelola dan meningkatkan kepuasan pelanggan untuk meningkatkan retensi pelanggan (Fornell, 1992). 
Kualitas layanan adalah salah satu faktor yang dapat mempengaruhi kepuasan pelanggan. Oleh karena itu, perusahaan harus dapat meningkatkan kualitas layanan atau service quality. Saat ini kesadaran konsumen akan pentingnya kualitas layanan sangat meningkat, Khusunya pada online shop dengan kualitas layanan yang baik akan berdampak kepada kepuasan pelanggan, sehingga perusahaan dapat mencapai nilai pelanggan dan perusahaan dapat dipercaya oleh pelanggan (Lupiyoadi dan Rambat, 2001) bagi konsumen pelayanan yang baik akan membuat perbedaan dengan pesaing, maka konsumen akan menilai apakah pelayanan yang diberikan perusahaan sesuai atau tidak dengan apa yang diharapkan oleh konsumen. Selain kualitas layanan, kepercayaan merupakan faktor lain yang mempengaruhi kepuasan pelanggan. Pelanggan yang percaya akan membentuk tingkat kepuasan yang tinggi sehingga dapat mendorong pelanggan untuk melalukan pembelian ulang. Disisi lain keberhasilan sebuah traksaksi dengan menggunakan internet sangat besar dipengaruhi oleh kepercayaan (Pavlou, 2003), Sehingga penting untuk perusahaan untuk menciptakan kepercayaan yang nantinya akan berdampak terhadap kepuasan pelanggan.

Salah satu permasalahan yang ingin dikaji dalam penelitian ini adalah faktor atau variabel mana yang mempengaruhi kepuasan pelanggan pada salah satu online shop, serta mengkaji variabel manakah yang tidak mempengaruhi kepuasan pelanggan pada online shop tersebut. Dengan demikian penelitian ini dilakukan guna untuk menguji secara empiris apakah kualitas layanan dan kepercayaan berpengaruh terhadap kepuasan pelanggan. Hasil penelitian ini diharapkan dapat memberikan kontribusi kepada perusahaan untuk mengetahui variabel apa saja yang mempengaruhi kepuasan pelanggan. Tujuan dilakukan penelitian ini untuk mengetahui dan menganalisa pengaruh dari kualitas pelayanan terhadap kepuasan pelanggan pada salah satu online shop dan untuk mengetahui dan menganalisa pengaruh dari kepercayaan terhadap kepuasan pelanggan pada salah satu online shop.

\section{TINJAUAN PUSTAKA}

\section{Kualitas Layanan}

Wijaya (2011:52) memaparkan "Kualitas Layanan adalah ukuran seberapa bagus tingkat layanan yang diberikan mampu sesuai dengan ekspetasi pelanggan." Selanjutnya "Service quality is the outcome of an evaluation process where the consumer compares his expectations with the perception of the service provided" (Gronroos 2006 dalam Silvestri, Aquilani dan Ruggieri 2016:58).

\section{Kepercayaan}

Bernarto dan Patricia (2017:39) mengungkapkan "Trust adalah keyakinan konsumen mengenai karakteristik dari pemasok dan perilaku pemasok dimasa yang akan datang." Selanjutnya trust adalah "Ketika satu kelompok memiliki keyakinan bahwa partner pertukaran memiliki reliabilitas dan integritas" (Morgan dan Hunt 1994 dalam Tjahyadi 2006: 71).

\section{Kualitas Layanan}

Han dan Ryu (2009: 492) menjelaskan "customer satisfaction is an overall judgement process of the perceived discrepancy between proir expectation and actual consumption." Selanjutnya Kotler dan Keller (2009:164), menjelaskan service quality adalah: "Satisfaction is a person's feeling of pleasure or disappointment resulting from comparing product's perceived performance (or outcome) in relation to this or her expectation." 


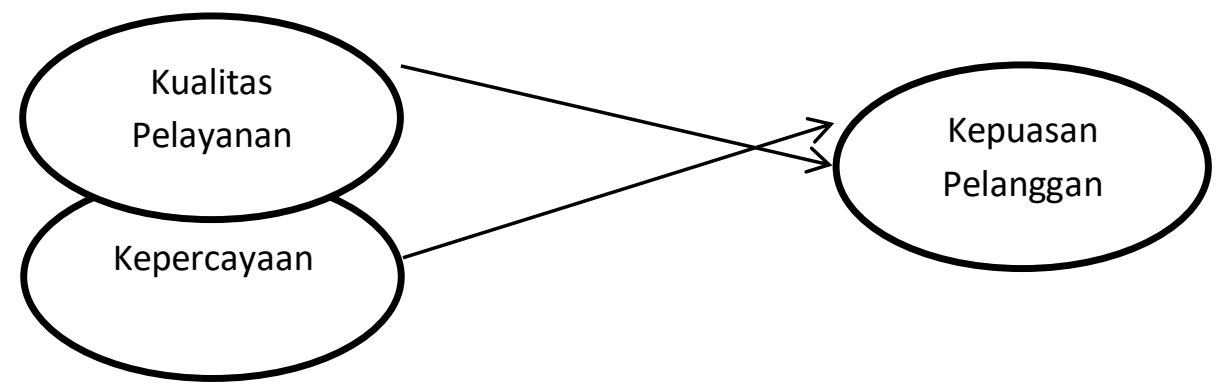

Gambar 1. Model Penelitian

\section{Kaitan Antara Kualitas Layanan dan Kepuasan Pelanggan}

Sasongko dan Subagio (2013), menyatakan bahwa kelima dimensi dari kualitas layanan yang diberikan kepada pelanggan memiliki dampak positif dan signifikan terhadap kepuasan pelanggan. Selanjutnya Kasim dan Abdullah (2010), menyatakan kualitas layanan yang baik secara positif berpengaruh terhadap kepuasan pelanggan. Sedangkan Abdullah dan Rozario (2009) menyatakan bahwa kualitas layanan memiliki hubungan yang positif terhadap kepuasan pelanggan. Berdasarkan uraian di atas, maka hipotesis penelitian adalah:

H1: Kualitas Layanan berpengaruh positif terhadap kepuasan pelanggan.

\section{Kaitan Antara Kepercayaan dan Kepuasan Pelanggan}

Victor, Jorie dan Sumarauw (2015) menyatakan bahwa kepercayaan memiliki hubungan yang signifikan terhadap kepuasan pelanggan. Selanjutnya Liaw, Jen dan Liang (2013), menjelaskan bahwa kepercayaan berpengaruh positif dan signifikan terhadap kepuasan pelanggan. Sementara Kundu dan Datta (2014) mengungkapkan bahwa kepercayaan berhubungan secara positif dan signifikan terhadap kepuasan pelanggan. Berdasarkan uraian di atas, maka $\mathrm{H} 2$ adalah:

\section{H2: Kepercayaan berpengaruh positif terhadap kepuasan pelanggan.}

\section{Metode Penelitian}

Jenis penelitian ini adalah penelitian deskriptif dengan pendekatan cross-sectional. Data mengenai variabel penelitian antara lain: kualitas layanan dan kepercayaan terhadap kepuasan pelanggan dikumpulkan pada waktu tertentu. Untuk mengukur variabel penelitian beberapa pernyataan diadaptasi dari penelitian terdahulu. Tabel 1 menunjukan pengukuran variabel penelitian ini beserta sumbernya. Skala pengukuran menggunakan skla interval dengan 1 menunjukan "sangat tidak setuju" dan 5 menunjukan "sangat setuju"Hasil analisis data reliabilitas dan validitas menunjukan bahwa semua variabel valid dan reliabel. Dikatakan valid untuk semua item pernyataan karena $r$ hitung lebih kecil dari pada $r$ tabel dan dikatakan reliabel karena Cronbach Alpha lebih besar dari 0,6. 
Tabel 1. Variabel dan Pengukuran

\begin{tabular}{|l|c|l|}
\hline \multicolumn{1}{|c|}{ Variabel } & Item & \multicolumn{1}{|c|}{ Sumber } \\
\hline $\begin{array}{l}\text { Variabel Bebas: } \\
\text { Kualitas layanan }\end{array}$ & 18 & $\begin{array}{l}\text { Swaid dan Wigand (2007) dan } \\
\text { Stiakakis dan Georgiadis (2009) }\end{array}$ \\
Kepercayaan & 4 & Lau dan Lee (1990) \\
\hline $\begin{array}{l}\text { Variabel Tidak Bebas: } \\
\text { Kepuasan Pelanggan }\end{array}$ & 5 & $\begin{array}{l}\text { Gunarathne (2014) dan Zhu, Sun } \\
\text { dan Chang (2016) }\end{array}$ \\
\hline
\end{tabular}

Populasi dalam penelitian ini adalah seluruh pengguna dari perusahaan. Sementara sampel dalam penelitian ini adalah 186 responden dari pengguna perusahaan di Jakarta. Metode penarikan sampel yang digunakan adalah metode nonprobability sampling dengan menggunakan teknik Conveniance Sampling. Berdasarkan data yang dikumpulkan, diketahui bahwa mayoritas responden perusahaan adalah perempuan yang berusia 18-23 tahun, berpendidikan Sarjana (S1/S2/S3), berprofesi sebagai pegawai swasta, dengan berbelanja 1 bulan terakhir, selanjutnya jenis produk yang banyak dibeli adalah elektonik dan menggunakan Smartphone untuk berbelanja di perusahaan. Penelitian ini menggunakan metode survei secara online melalui Google Form dengan kuesioner terstruktur untuk mengumpulkan data mengenai masing-masing variabel penelitian. Analisis regresi berganda digunakan untuk menguji apakah kualitas layanan dan kepercayaan dapat mempengaruhi kepuasan pelanggan. Pengujia asumsi klasik seperti uji normalitas, uji multikolinietitas dan uji heteroskedastisitas dilakukan sebelum analisis regresi berganda dan hasilnya menunjukan semua uji asumsi terpenuhi. Nilai signifikan yang digunakan dalam penelitian ini sebesar 5 $\%$.

\section{Hasil dan Pembahasan}

Hasil analisis data secara singkat tertera pada Tabel 2. Berdasarkan tabel tersebut dapat diperoleh bahwa variabel prediktor yang positif terhadap kepuasan pelanggan adalah kepercayaan, selanjutnya diikuti kualitas layanan. Hal ini menunjukan tingginya kepuasan pelanggan, dapat dijelaskan oleh tingginya kepercayaan dan kualitas layanan. Hasil pengujian hipotesis secara parsial menunjukan bahwa $(\mathrm{H} 1)$, kualitas layanan dan $(\mathrm{H} 2)$, kepercayaan berpengaruh positif terhadap kepuasan pelanggan.

Tabel 2. Analisis Regresi Berganda

\begin{tabular}{|c|c|c|c|c|c|}
\hline \multirow[t]{2}{*}{ Model } & \multicolumn{2}{|c|}{$\begin{array}{c}\text { Unstandarlized } \\
\text { Coefficients }\end{array}$} & $\begin{array}{c}\text { Standarlized } \\
\text { Coefficients }\end{array}$ & \multirow[t]{2}{*}{$\mathrm{t}$} & \multirow[t]{2}{*}{ Sig } \\
\hline & $\mathrm{B}$ & $\begin{array}{c}\text { Std } \\
\text { Error }\end{array}$ & beta & & \\
\hline Constant & $\begin{array}{c}- \\
0,615\end{array}$ & 1,290 & & $-0,477$ & 0,634 \\
\hline Service quality & 0,196 & 0,021 & 0,548 & 9,180 & 0,000 \\
\hline Kepercayaan & 0,490 & 0,099 & 0,295 & 4,946 & 0,000 \\
\hline
\end{tabular}

Hasil penelitian variabel secara partial, variabel (X1) service quality sama dengan penelitian Sasongko dan Subagio (2013) dan Kasim dan Abdullah (2010) yang menunjukan bahwa service quality mempunyai pengaruh positif terhadap kepuasan pelanggan. Ketika kinerja perusahaan baik atau sesuai dengan apa yang diharapkan pelanggan maka akan berdampak terhadap kepuasan pelanggan. Sebaliknya pelanggan yang tidak puas mununjukan bahwa kualitas layanan yang diberikan pelanggan tidak sesuai dengan apa yang 
diharapkan oleh pelanggan. Sedangkan hasil untuk variabel (X2) kepercayaan sama dengan penelitian Liaw, Jen dan Liang (2013) dan Victor, Jorie dan Sumarauw (2015) yang menunjukan bahwa kepercayaan mempunyai pengaruh positif terhadap kepuasan pelanggan. Semakin kuat kepercayaan akan membuat kepercayaan semakin kuat. Karena konsumen yang percaya terhadap kredibilitas dan kemampuan perusahaan akan berdampak terhadap meningkatnya kepuasan pelanggan.

\section{Kesimpulan dan Saran}

Kesimpulan dalam penelitian ini menunjukan bahwa Service quality berpengaruh positif terhadap kepuasan pelanggan pada salah satu online shop di Jakarta dan Kepercayaan berpengaruh positif terhadap kepuasan pelanggan pada salah satu online shop di Jakarta. Selanjutnya peneliti menyarankan agar perusahaan memperhatikan faktor service quality dalam menentukan strategi dengan lebih memperhatikan form saran yang diberikan oleh pelanggan dan cepat tanggap dengan keluhan yang diajukan oleh pelanggan, seperti customer service yang selalu sedia selama 24 jam untuk membantu menyelesaikan keluhan dari pelanggan, sehingga nantinya dapat menentukan strategi yang tepat untuk meningkatkan service quality dari perusahaan dan tetap mempertahankan faktor kepercayaan dengan memberi berbagai bentuk kemananan dalam melakukan transaksi, seperti adanya verifikasi ketika pelanggan menggunakan kartu kredit dalam melakukan pembayaran dan tetap menjaga privasi pelanggan yang dapat meningkatkan kepercayaan.

\section{DAFTAR PUSTAKA}

Abdullah, D.N.M.A., \& Rozario, F. (2009). Influence of Service and Product Quality towards Customer Satisfaction: A Case Study at the Staff Cafeteria in the Hotel Industry. International Scholarly and Scientific Research \& Innovation, 3(5), 346-351.

Bernarto, I., \& Patricia. (2017). Pengaruh Perceived Value, Customer Satisfaction dan Trust terhadap Customer Loyality Restoran XYZ di Tangerang. Journal for Business and Entrepreneur, 1(1), 36-49.

Fornell, C. (1992) A National Customer Satisfaction Barometer: The Swedish Experience. Journal of Marketing, 56.

Gunarathne, U. (2014). Relationship between Service Quality and Customer Satisfaction in Sri Lanka Hotel Industry. International Journal of Scientific and Research Publication, 4(11), 18.

Han, H., \& Ryu, K. (2009). The Roles of the Physical Environment, Price Perception, and Customer Satisfaction in Determining Customer Loyalty in the Restaurant Industry. Journal of Hospitality \& Tourism Research, 33(4), 487-510. Doi:10.1177/1096348009344212

Kassim, N., \& Abdullah, N.A., (2010). The Effect of Perceived Service Quality Dimensions on Customer Satisfaction, Trust and Loyality in e-Commerce Settings: A Cross Cultural Analysis. Asia Pacific Journal of Marketing, 22(3), 351-371.

Kundu, S., \& Datta, S.K. (2015). Impact of Trust on the Relationship of e-Service Quality and Customer Satisfaction. EuroMed Journal of Business, 10(1), 21-46. Doi:10.1108/EMJB-102013-0053

Lau, G., \& Lee, S.H. (1999). Consumers Trust in a Brand and the Link to Brand Loyalty. Journal of Market Focused Management, 341-370.

Liaw, G.F., Jen, F., \& Liang, S.H. (2013). The Effect of Trust Satisfaction and Switching Cost on Consumer Loyalty A Model of on Line Auction. Journal of International Management Studies, 8(1), 59-67.

Lupiyoadi, R. (2001). Manajemen Pemasaran Jasa Teori dan Praktik. Jakarta: Salemba Empat. 
Pavlou, P.A. (2003). Consumer Acceptance of Electronic Commerce: Integrating Trust and Risk with the Technology Acceptance Model. International Journal of Electronic Commerce, 7(3), 69-103.

Sasongko, F., \& Subagio, H. (2013). Pengaruh Kualitas Layanan Terhadap Kepuasan Pelanggan Restoran Ayam Penyet Ria. Jurnal Manajemen Pemasaran Petra, 1(2), 1-7.

Silvestri, C., Aquilani, B., \& Ruggieri, A. (2016). Service Quality and Customer Satisfaction in Thermal Tourism. EuroMed Journal of Business, 29(1), 55-81.

Stiakakis, E,. \& Georgiadis, C.K. (2009). E-service Quality the Perceptions of Providers and Customers. International Jurnal, 19(4), 410-430.

Swaid, S.I., \& Wigand, R.T. (2007). Key Dimensions of E-commerce Service Quality and Its Relationships to Satisfaction and Loyalty. Journal of the Association for Information Systems, 29, 414-428.

Tjahyadi, R.A. (2006). Brand Trust dalam Konteks Loyalitas Merek: Peran Karakteristik Merek, Karakteristik Perusahaan, dan Karakteristik Hubungan Pelanggan-Merek. Jurnal Manajemen, 6(1), 65-78.

Victor, C., Jorie, R.J., \& Sumarauw, J.S.B. (2015). Pengaruh Customer Relationship Management dan Kepercayaan terhadap Kepuasan Serta Dampaknya terhadap Loyalitas Konsumen PT. Bank BCA Tbk. di Manado. Jurnal EMBA, 3(2), 671-683.

Wijaya, T. (2011). Manajemen Kualitas Jasa. Jakarta: Penerbit PT Indeks.

Zhu, D.H., Sun, H., Chang, Y.P. (2016). Effect of Social Support on Customer Satisfaction and Citizenship Behavior in Online Brand Communities: The Moderating Role of Support Source. Journal of Retailing and Consumer Services, 31, 287-293. 
